\title{
24. GEOCHEMICAL STUDIES OF BLACK CLAYS FROM LEG 43, DEEP SEA DRILLING PROJECT
}

\author{
J. W. Kendrick, Shell Development Company, P. O. Box 481, Houston, Texas
}

\begin{abstract}
Geochemical studies of Cretaceous-age black clays from DSDP Sites 386 and 387 indicate that the organic matter in the sediments is derived from two different sources. Hydrogen-rich, amorphous organic matter is apparently derived from marine planktonic organisms, while organic matter rich in vitrinite and thermally inert material is terrigenous.

The relative amounts of marine and terrestrial organic matter are strongly influenced by the degree to which water conditions were reducing at the time of deposition. The distribution of iron and sulfur within the sediments suggests that marine organic matter was preserved when sulfate-reducing conditions developed at, or near, the sea floor. Under aerobic conditions, only the more stable, terrestrial organic matter escaped oxidative destruction.

Variations in the organic composition, sulfur content, and iron geochemistry of the sediments imply that the bottom water conditions changed frequently during deposition of the black clays. The fluctuations between alternately aerobic and anaerobic bottom conditions were probably caused by changes in the organic productivity of surface waters and in the amounts of oxygen supplied by deep water circulation.
\end{abstract}

\section{INTRODUCTION}

The Deep Sea Drilling Project (DSDP) has documented the widespread occurrence of Cretaceous organic-carbon-rich black clays in the North Atlantic Ocean (Lancelot et al., 1972; Berger and von Rad, 1972; Lancelot, Seibold, et al., in press.) The term "black clay" is commonly used to describe the entire sequence which consists of interbedded black and dark greenish gray, fine-grained sediments. These sediments represent a major period of reducing conditions in the Atlantic during its early history.

Lancelot et al. (1972) and Berger and von Rad (1972) have discussed the occurrence and lithologic composition of black clays in the North Atlantic Ocean. Surprisingly, very little work has been devoted to examining the geochemistry of these sediments. The intent of this study was to collect geochemical information which would aid in understanding the depositional environment of the black clays. Particular attention was directed toward determining the composition and origin of organic matter in the sediments as well as evaluating the effects of reducing conditions on the distribution of certain inorganic constituents within the sediments.

The Cretaceous sediments analyzed in this study come from DSDP Sites 386 and 387 on the Bermuda Rise (Figure 1). At Site 386 the black clay unit is some 240 meters thick and directly overlies basaltic basement. The sediments are well dated, ranging from early Albian to late Cenomanian (see Site 386 sum-

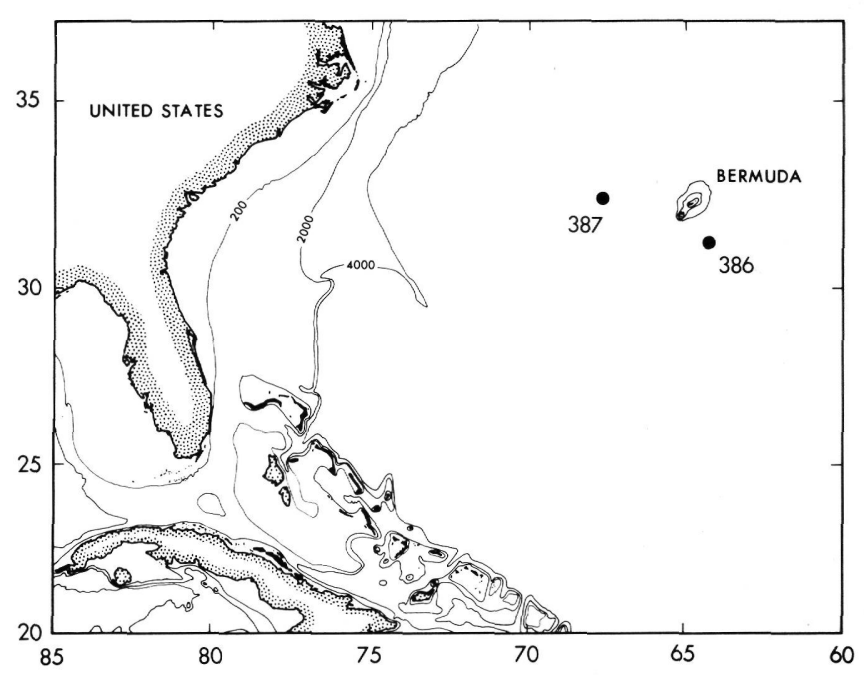

Figure 1. Location map. Depth contours in meters.

mary). At Site 387 , on the other hand, the black clay interval is only about 100 meters thick, but it spans the interval from Barremian/Aptian to Cenomanian Habib, this volume). The black clays at Site 387 are overlain, perhaps disconformably, by Campanian red claystones, and they grade downward into Barremian and Neocomian limestones. The limestones contain numerous thin beds and laminae of organic-carbon-rich marly chalk, indicating that reducing conditions existed very early in the Cretaceous. 
The lithology of sediments at Sites 386 and 387 is described in the respective site summary chapters of this volume. The dark-colored claystones examined in this study (Table 1) were chosen to represent the variety of lithologies within the black-clay units. In several instances, closely spaced samples were taken to examine small-scale variations in geochemistry.

\section{ANALYTICAL PROCEDURE}

Both whole-sediment samples and kerogens which had been chemically separated from the sediment were analyzed. Before analytical work began, the sediment samples were dried overnight at $60^{\circ} \mathrm{C}$ and then homogenized.

\section{Whole-Sediment Analyses}

Both organic carbon $\left(\mathrm{C}_{\mathrm{org}}\right)$ and effective carbon $\left(\mathrm{C}_{\mathrm{cff}}\right)$ contents of the sediment samples were determined. Organic carbon, or acid-insoluble carbon, is determined by LECO combustion analysis as a measure of the total organic matter in the sediment. Effective carbon, on the other hand, is used to indicate what fraction of the organic carbon is thermally convertible to hydrocarbons and hydrocarbon-like compounds.

Effective carbon content is determined by means of a pyrolysis-FID technique. A small amount of sample is pyrolyzed in a flowing stream of nitrogen from room temperature to $650^{\circ} \mathrm{C}$ at a rate of $25^{\circ} \mathrm{C}$ per minute. The volatile products of the pyrolysis are carried to a hydrogen flame ionization detector (FID) for measurement, and the signal from the detector is converted to percent hydrocarbons by calibration with a petroleum wax. $\mathrm{C}_{\text {eff }}$ is calculated at 85 per cent of the hydrocarbons generated in the temperature range of $300^{\circ}$ to

TABLE 1

Sediment Samples

\begin{tabular}{|c|c|c|}
\hline $\begin{array}{c}\text { Sample } \\
\text { (Interval in } \mathrm{cm} \text { ) }\end{array}$ & $\begin{array}{l}\text { Depth } \\
\text { (m) }\end{array}$ & Lithology \\
\hline \multicolumn{3}{|l|}{ Site 386} \\
\hline $42-3,30-32$ & 730 & Black radiolarian sand \\
\hline $43-3,103-107$ & 740 & Micro-laminated, brown-black claystone \\
\hline $43-3,107-110$ & 740 & Brown-black claystone; abundant radiolaria \\
\hline $44-3,102-104$ & 750 & Black chert \\
\hline $44-4,129-134$ & 752 & Mottled, dark greenish gray claystone \\
\hline $44-4,134-137$ & 752 & Black, radiolarian mudstone \\
\hline $44-4,137-141$ & 752 & Laminated, dark gray to dark olive-gray marly chalk \\
\hline $44-4,141-145$ & 752 & Laminated, dark gray to dark olive-gray marly chalk \\
\hline $44-4,145-150$ & 752 & Laminated, dark gray to dark olive-gray marly chalk \\
\hline $45-4,66-68$ & 770 & Very dark gray claystone \\
\hline $45-4,68-72$ & 770 & Dark olive-gray claystone \\
\hline $47-4,25-27$ & 789 & Mottled, dark greenish gray claystone \\
\hline $47-4,27-31$ & 789 & Laminated, olive gray marly chalk \\
\hline $47-4,37-39$ & 789 & Dark olive-gray claystone, with $\mathrm{CaCO}_{3}$-rich laminae \\
\hline $47-4,43-45$ & 789 & Gray-black claystone \\
\hline $61-1,115-118$ & 918 & Dark gray claystone \\
\hline 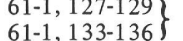 & 918 & Mottled, dark greenish gray claystone \\
\hline $61-1,129-133$ & 918 & Dark gray claystone \\
\hline $61-2,10-15$ & 918 & Mottled, dark greenish gray and dark gray claystone \\
\hline \multicolumn{3}{|l|}{ Site 387} \\
\hline $30-1,142-144$ & 490 & Brownish black claystone \\
\hline $32-6,41-44$ & 515 & Mottled, black and gray claystone \\
\hline $39-2,43-46$ & 623 & Laminated, dark olive-gray marly chalk \\
\hline $44-1,123-125$ & 680 & Laminated, greenish gray chalk \\
\hline
\end{tabular}

$650^{\circ} \mathrm{C}$. It does not include pre-existing volatile material which is distilled from the sample at lower temperatures.

Another pyrolysis method, pyrolysis flourescence (PF), is used as a rapid means of determining organic carbon (Heacock and Hood, 1970). A 0.1-g sample is heated in a culture tube until the sample and tube become red-hot and then allowed to cool. Three $\mathrm{ml}$ of chlorothene (1,1,1-Trichloroethane) is added, and the contents are decanted into a clean tube. The amount of soluble fluorescing compounds is measured with a Turner Model 110 fluorometer, modified by the addition of a 99 per cent opaque neutral-density filter. Samples with fluorometer readings greater than 20 are diluted with known volumes of chlorothene to avoid self-absorption effects. Using the appropriate dilution factor, PF values are calculated as scale readings per $0.1 \mathrm{~g}$ of sample in $3 \mathrm{ml}$ of solvent. PF values of rocks typically range from zero to several thousand units.

\section{Kerogen Analyses}

For isolating kerogen, or insoluble organic matter, the sediment is extracted with a mixture of 60 per cent benzene and 40 per cent methanol for 24 hours in a Soxhlet apparatus. The extracted sample is then treated with $6 N$ hydrochloric acid and filtered to remove calcium carbonate. Silicate minerals are subsequently removed by repeated treatments, first with concentrated hydrofluoric acid and then with concentrated hydrochloric acid. During the acid treatment, the sample is heated at $50-60^{\circ} \mathrm{C}$ to aid in vaporizing the volatile fluoride compounds. Finally, the sample is rinsed with distilled water, filtered, and dried at $60^{\circ} \mathrm{C}$ under nitrogen. The residue contains kerogen, pyrite, and minor amounts of fluorides and silicates.

The kerogen isolation procedure worked satisfactorily, except for one sample of a greenish gray claystone which, after acid treatment, contained large amounts of residual fluoride salts (Table 2). X-ray diffraction indicated that weakly soluble aluminum fluorides were

TABLE 2

Chemical Composition of Kerogen Concentrates (per cent) ${ }^{\mathrm{a}}$

\begin{tabular}{lrrrrrrrr}
\hline $\begin{array}{c}\text { Sample } \\
\text { (Interval in cm) }\end{array}$ & $\mathrm{C}$ & $\mathrm{O}$ & $\mathrm{H}$ & $\mathrm{N}$ & $\mathrm{S}$ & $\mathrm{Fe}$ & $\mathrm{Si}$ & $\mathrm{F}$ \\
\hline Site 386 & & & & & & & & \\
$43-3,103-107$ & 45.5 & 23.2 & 5.0 & 1.2 & 12.6 & 6.3 & $<0.5$ & 0.54 \\
$43-3,107-110$ & 51.4 & 10.3 & 5.6 & 1.3 & 16.2 & 7.6 & $<0.5$ & 0.27 \\
$44-4,129-134$ & 8.7 & 10.6 & 1.1 & 0.3 & - & $18 \mathrm{a}$ & 1.9 & 23. \\
$44-4,134-137$ & 49.1 & 9.5 & 3.1 & 1.5 & 17.8 & 12.6 & $<0.5$ & 0.82 \\
$44-4,137-141$ & 45.7 & 10.2 & 3.8 & 1.9 & 16.0 & 12.0 & 0.5 & 0.71 \\
$44-4,141-145$ & 39.4 & 10.4 & 3.5 & 1.6 & 18.9 & 15.6 & $<0.5$ & 0.31 \\
$44-4,145-150$ & 40.2 & 9.8 & 3.5 & 1.6 & 22.7 & 17.1 & $<0.5$ & 0.41 \\
$47-4,27-31$ & 52.7 & 13.6 & 4.4 & 2.2 & 9.6 & 7.6 & $<0.5$ & 3.9 \\
$47-4,37-39$ & 41.4 & 11.7 & 2.9 & 1.2 & 18.4 & 13.7 & 3.6 & 0.19 \\
$47-4,43-45$ & 33.9 & 7.9 & 2.1 & 1.0 & 11.7 & 10.4 & 6.1 & 12. \\
$61-1,127-129$ & 25.7 & 10.3 & 1.5 & 0.8 & 31. & 25.1 & - & 3.6 \\
$61-1,133-136$ & & & & & & & & \\
Site 387 & & & & & & & & \\
$30-1,142-144$ & 54.0 & 16.1 & 5.5 & 1.6 & 13.3 & 8.3 & $<0.5$ & 0.27 \\
$39-2,43-46$ & 53.9 & 11.1 & 4.6 & 2.2 & 13.6 & 8.5 & $<0.5$ & 0.19 \\
\hline a Analysis by emission spectroscopy. & & & & & &
\end{tabular}

aAnalysis by emission spectroscopy. 
still present. Hydroxyl and water groups associated with some of the fluoride compounds precluded the accurate determination of hydrogen and oxygen in the organic matter of that sample.

The composition of the isolated kerogen is determined by the following techniques:

1) Carbon, hydrogen, and nitrogen are analyzed with a Perkin-Elmer Model $240 \mathrm{CHN}$ analyzer.

2) Oxygen and fluorine are determined by $14 \mathrm{MeV}$ neutron activation analysis. Two different irradiations are performed. In the first, the amount of ${ }^{19} \mathrm{O}$ formed by the reaction ${ }^{19} \mathrm{~F}(\mathrm{n}, \mathrm{p})^{19} \mathrm{O}$ is measured to determine the fluorine content of the sample. In the second irradiation, oxygen and fluorine are determined together by measuring the ${ }^{16} \mathbf{N}$ formed in the reactions ${ }^{16} \mathrm{O}(\mathrm{n}, \mathrm{p})^{16} \mathrm{~N}$ and ${ }^{19} \mathrm{~F}(\mathrm{n}, \propto)^{16} \mathrm{~N}$. By subtracting out the effect of fluorine, the oxygen content can then be computed.

3 ) Iron, in the kerogen concentrate and the whole rock, and silicon are determined by atomic absorption spectrophotometry. The kerogen sample is prepared for analysis by fusing it with lithium metaborate at $1000^{\circ} \mathrm{C}$ and then dissolving the product in 50 per cent $\mathrm{HCl}$. The iron content of the kerogen concentrate is used to calculate the amount of pyrite in the kerogen.

4) The sulfur contents of the kerogen concentrate and whole sediment are determined by the LECO combustion technique. The pyrite sulfur content of the kerogen concentrate is computed from the measurement of pyrite iron. The amount of organic sulfur is calculated by subtracting the computed value of pyrite sulfur from the measured sulfur content of the kerogen concentrate.

The amounts of pyrite and organic sulfur in the kerogen fraction are converted to whole-rock values by using the ratio of organic carbon in the whole rock to total carbon in the kerogen. The values of total sulfur calculated in this way agree well with actual measurements of total sulfur in the whole sediment. By subtracting the amount of pyrite iron from the total iron content of the sediment, it is possible to compute the amount of non-pyrite iron in the whole rock.

Visual observations of the kerogen were made by means of reflected light microscopy as described by Hood et al. (1976).

\section{RESULTS AND DISCUSSION}

\section{Content of Organic Matter}

Shipboard measurements of organic carbon at Site 386 (see Site 386 summary chapter) suggested that organic-carbon-rich sediments occur primarily near the top and the bottom of the black claystone unit, with low values $\left(<1 \% \mathrm{C}_{\mathrm{org}}\right)$ at intermediate depths. To verify that trend, a more detailed survey of content of organic matter was made using pyrolysis fluorescence (PF). The PF data, together with additional measurements of organic carbon by Cameron (this volume), are illustrated in Figure 2. The highest organic carbon contents are still found near the top and base of the black clay unit. The organic carbon values at intermediate depths $(760-900 \mathrm{~m})$ often exceed 1 per cent, however, obscuring somewhat the trends in organic carbon that were observed onboard ship. The profile of pyrolysis fluorescence values shows more clearly that large differences in the organic-matter content of the black clays do exist. Most PF values greater than 100 units occur in the upper 40 meters and lower 70 meters of the black clay sequence, while the intervening sediments commonly have PF values of less than 10 units.

Because the black clay interval at Site 387 was incompletely cored and because stratigraphic gaps appear to exist within the interval (McCave, this volume), it is difficult to compare the trends in organic carbon and pyrolysis fluorescence at Site 386 with those of time-equivalent, Albian-Cenomanian sediments at Site 387 (Figure 3). The most obvious similarity in the distribution of organic matter at both sites is the occurrence of very high $\mathrm{C}_{\text {org }}$ and $\mathrm{PF}$ values near the top of the black clay unit. These large concentrations of organic matter further appear to be correlative with high contents of organic matter in the black clays at Site 105 (DSDP Leg 11; Boyce, 1972). This similarity in the carbon content of the black clays at three different sites suggests that stratigraphic variations in the distribution of organic matter may be regionally significant. Variations through time of the proportion of organic matter may reflect major changes in such factors as organic productivity or the preservation of organic matter.

Organic carbon content of the sediments varies considerably over short intervals with changes in lithology, possibly reflecting short-term changes in the depositional environment. The relationship of organic content to readily observable features of the sediment such as color and sedimentary structures, however, is not completely clear. While the mottled, greenish gray claystones consistently contain little organic carbon, the black and dark gray claystones exhibit a wide range of $\mathrm{C}_{\text {org }}$ and PF values. Similarly, the carbon content of laminated and homogeneous sediments is too variable for sedimentary structures to be useful indicators of the abundance of organic carbon.

\section{Composition of Organic Matter}

As one means of describing the organic matter in Cretaceous sediments, the elemental composition of kerogen concentrates from several samples was determined. The results of the chemical analyses are summarized in Tables 2 and 3.

Tissot et al. (1974) have shown that the elemental composition of kerogen can be used to classify different types of organic matter. Such kerogen types group organic matter from similar depositional environments, and they correspond to different macerals found in coals.

The atomic ratios of $\mathrm{H} / \mathrm{C}$ and $\mathrm{O} / \mathrm{C}$ for the DSDP Leg 43 kerogens are plotted in Figure 4. The curved lines in the diagram represent the thermal evolution paths of the three kerogen types defined by Tissot et al. 


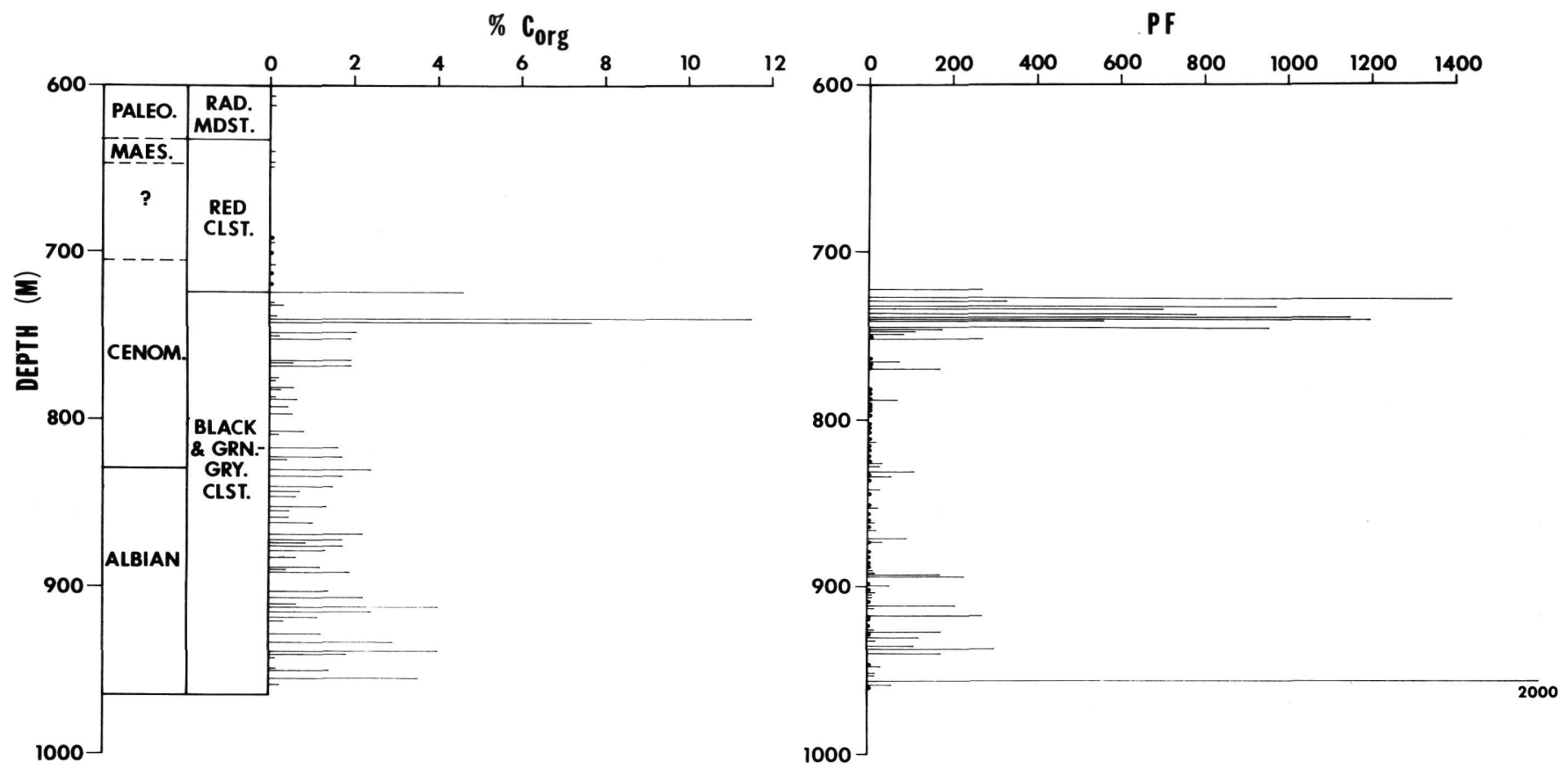

Figure 2. Profiles of organic carbon $\left(C_{\text {org }}\right)$ and pyrolysis fluorescence $(P F)$ versus depth in the lower 350 meters of Site 386. Values of organic carbon are taken from the site summary chapter and from Cameron (this volume). PF values are expressed in arbitrary units.

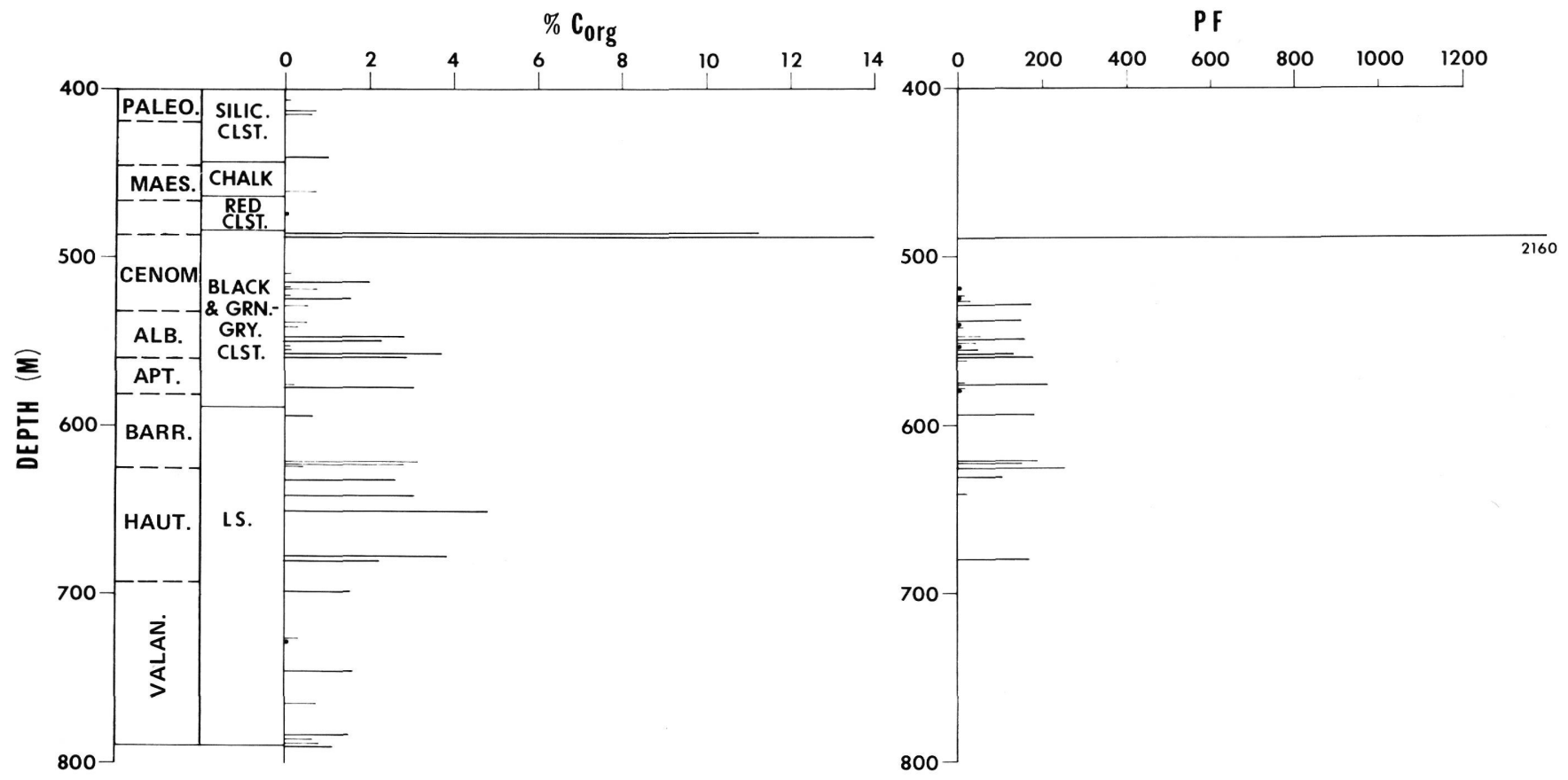

Figure 3. Profiles of organic carbon $\left(C_{\text {org }}\right)$ and pyrolysis fluorescence $(P F)$ versus depth in the lower 400 meters of Site 387. Values of organic carbon are taken from the site summary chapter and from Cameron (this volume). PF values are expressed in arbitrary units.

(1974). These evolution paths describe the changes in chemical composition which occur during organic metamorphism. The sediments at Sites 386 and 387 have been buried to similar depths and have not been exposed to very high subsurface temperatures. As a consequence, variations in organic composition should primarily reflect differences in original organic matter rather than thermal effects.

With the exception of two samples, whose $\mathrm{O} / \mathrm{C}$ ratios appear spuriously high, the organic matter from the Cretaceous sediments falls into three compositional ranges. Samples from Core 43 (Site 386) and Core 30 
TABLE 3

Normalized $^{\text {a }}$ Composition of Kerogen Concentrates

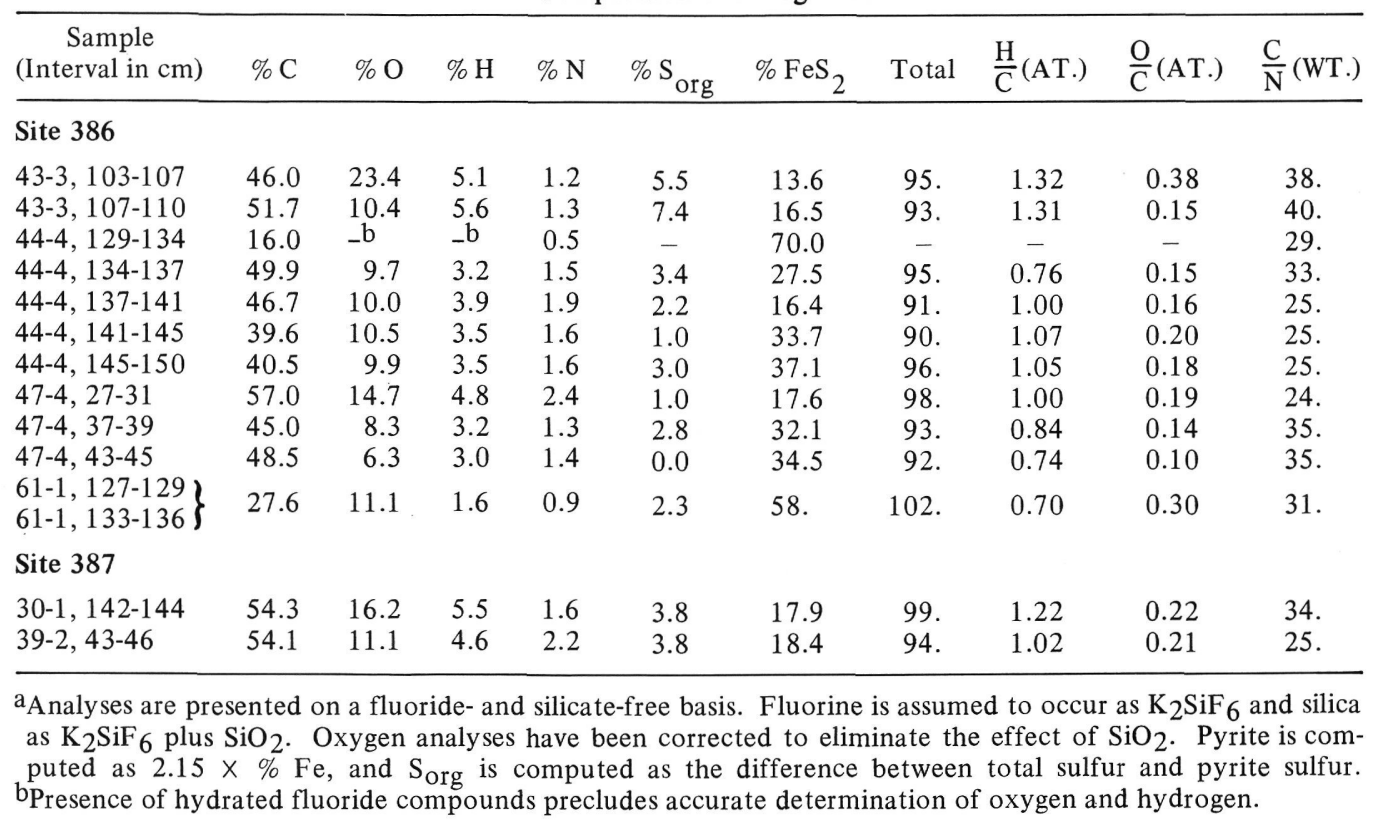

(Site 387) appear to correspond to the type II kerogen described by Tissot et al. (1974). Characterized by moderately high (1.3) H/C ratios, type II kerogens are considered by Tissot and Espitalié, (1975) to represent organic matter derived from aquatic organisms such as marine phytoplankton and zooplankton. Several other samples, from Cores 44 and 47 at Site 386, have very low $(0.7) \mathrm{H} / \mathrm{C}$ ratios and lie near the evolution path of Type III kerogen, representing humic, land-plant material (Tissot and Espitalié, 1975). The remaining samples have composition intermediate between type II and type III kerogens and most likely represent a mixture of marine and terrigenous organic matter.

The samples containing type III kerogen are noteworthy because their low $\mathrm{O} / \mathrm{C}$ values suggest that they have reached higher levels of organic metamorphism than stratigraphically adjacent kerogens of different composition. This observation implies that a large fraction of the land-plant material is not primary, but has been recycled from older sedimentary units with a prior thermal history. Vitrinite reflectance measurements of sediments from the black clay units at Sites 386 and 387 (Kendrick et al., this volume) support this conclusion. Several dark gray and dark greenish gray claystones exhibit reflectance values which are unusually high for their present depth of burial.

Because the task of isolating kerogens for elemental analysis is a tedious one, whole-rock analyses were used to aid in characterizing the organic matter. This was accomplished by using a pyrolysis method, pyrolysis-FID, which measures the sediment's effective carbon content, i.e., the carbon associated with hydrogen. The ratio of effective carbon to organic carbon should provide an index of organic type which is related to the $\mathrm{H} / \mathrm{C}$ ratio of a kerogen. Indeed, the relationship between $\mathrm{C}_{\text {eff }} / \mathrm{C}_{\text {org }}$ and $\mathrm{H} / \mathrm{C}$ is excellent (Figure 5).

The values of $\mathrm{C}_{\mathrm{eff}} / \mathrm{C}_{\text {org }}$ in Table 4 range from 0.03 to 0.57 . The relationship between $\mathrm{C}_{\text {eff }} / \mathrm{C}_{\text {org }}$ and $\mathrm{H} / \mathrm{C}$ in
Figure 5 indicates that the values of $\mathrm{C}_{\mathrm{eff}} / \mathrm{C}_{\mathrm{org}}$ in Table 4 correspond to a range of $\mathrm{H} / \mathrm{C}$ values $(0.7-1.3)$ which are the same as those of the kerogen concentrates in Figure 4. The histogram of $\mathrm{C}_{\mathrm{eff}} / \mathrm{C}_{\mathrm{org}}$ values in Figure 6 indicates that the samples form compositional groups which are similar to those in Figure 4. Most sediments have $\mathrm{C}_{\text {eff }} / \mathrm{C}_{\text {org }}$ ratios either less than 0.1 (corresponding to type III kerogen) or between 0.2 and 0.3 (reflecting a mixture of type II and type III kerogen). Only three samples have high enough $\mathrm{C}_{\text {eff }} / \mathrm{C}_{\text {org }}$ ratios $(\sim 0.5)$ to indicate a predominantly type II (marine) kerogen.

To characterize the organic matter of the black clays further, semi-quantitative visual estimates of maceral

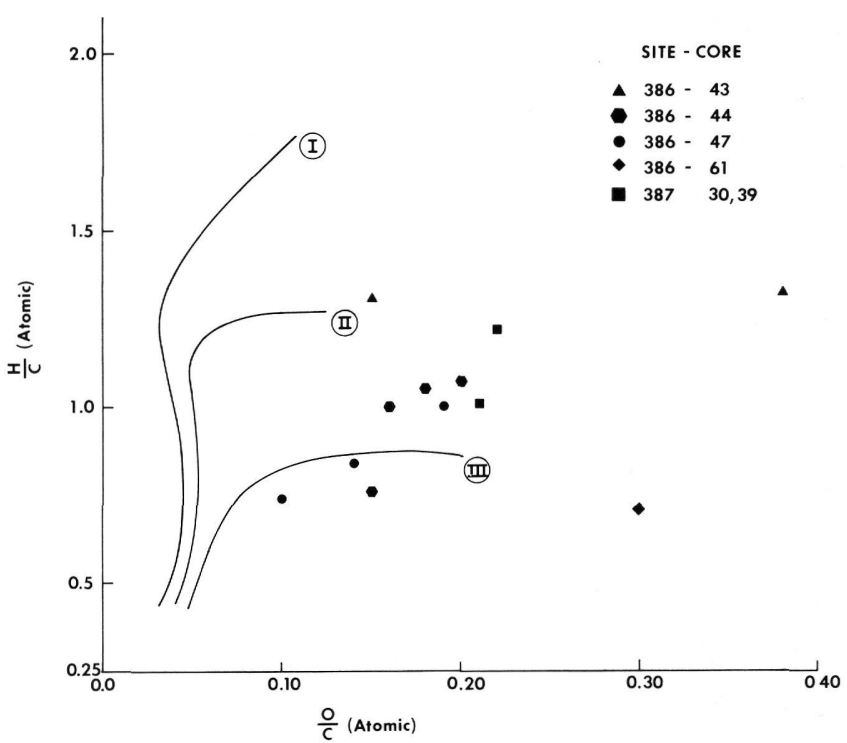

Figure 4. Graph depicting the atomic ratios of $\mathrm{H} / \mathrm{C}$ and $\mathrm{O} / \mathrm{C}$ for kerogen concentrates. The numbered curves represent evolution paths of kerogen composition for different types of kerogen (from Tissot et al., 1974). 


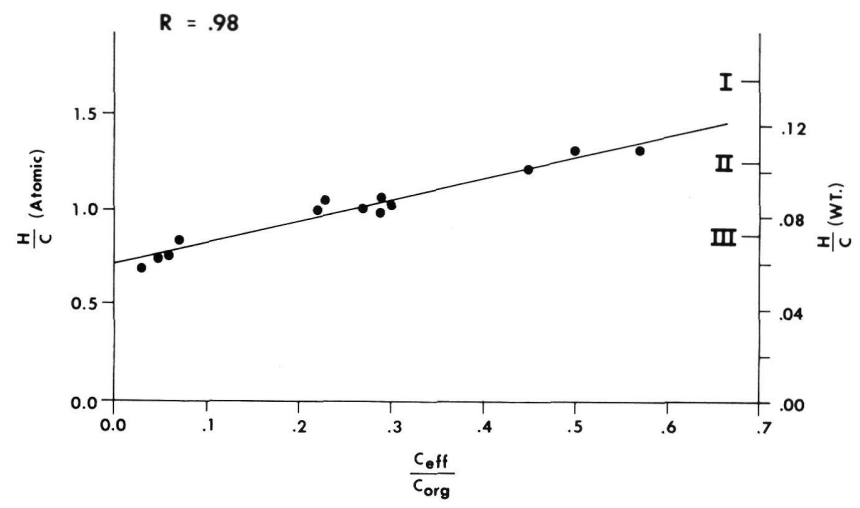

Figure 5. Graph relating $H / C$ ratios of kerogen concentrates to $C_{\text {eff }} / C_{\text {org }}$ ratios of the sediments from which the kerogens were isolated. The Roman numerals denote the $H / C$ ratios of Tissot et al.'s (1974) kerogen types. $\mathrm{R}$ is the correlation coefficient of the regression.

TABLE 4

Content of Organic Matter and Total Sulfur Content

\begin{tabular}{lcllrr}
\hline \multicolumn{1}{c}{$\begin{array}{c}\text { Sample } \\
\text { (Interval in cm) }\end{array}$} & \% $\mathrm{C}_{\text {org }}$ & $\%_{\text {eff }}$ & $\begin{array}{c}\mathrm{C}_{\text {eff }} \\
\mathrm{C}_{\text {org }}\end{array}$ & PF & $\% \mathrm{~S}$ \\
\hline Site 386 & & & & & \\
$42-3,30-32$ & 4.18 & 1.6 & 0.38 & 130 & 0.51 \\
$43-3,103-107$ & 14.3 & 7.2 & 0.50 & 1200 & 4.12 \\
$43-3,107-110$ & 8.44 & 4.8 & 0.57 & - & 2.97 \\
$44-3,102-104$ & 1.10 & 0.29 & 0.26 & 5 & 0.64 \\
$44-4,129-134$ & 0.23 & 0.01 & 0.03 & 1 & 0.32 \\
$44-4,134-137$ & 2.04 & 0.12 & 0.06 & 1 & 0.76 \\
$44-4,137-141$ & 4.19 & 1.2 & 0.29 & 250 & 1.71 \\
$44-4,141-145$ & 3.43 & 0.99 & 0.29 & 140 & 2.04 \\
$44-4,145-150$ & 1.65 & 0.38 & 0.23 & 45 & 0.92 \\
$45-4,66-68$ & 5.23 & 0.84 & 0.16 & 60 & 0.93 \\
$45-4,68-72$ & 5.15 & 1.3 & 0.25 & 165 & 1.71 \\
$47-4,25-27$ & 0.27 & 0.01 & 0.04 & - & 0.27 \\
$47-4,27-31$ & 2.50 & 0.55 & 0.22 & 68 & 0.48 \\
$47-4,37-39$ & 1.10 & 0.08 & 0.07 & - & 0.61 \\
$47-4,43-45$ & 1.03 & 0.05 & 0.05 & 2 & 0.40 \\
$61-1,115-119$ & 8.61 & 2.0 & 0.23 & 270 & 3.36 \\
$61-1,127-129$ & 0.84 & 0.02 & 0.03 & 1 & 1.02 \\
$61-1,133-136$ & 0.84 & & & & \\
$61-1,129-133$ & 8.50 & 1.82 & 0.21 & 225 & 4.27 \\
$61-2,10-15$ & 1.46 & 0.06 & 0.04 & 2 & 0.46 \\
Site 387 & & & & & \\
$30-1,140-142$ & 15.3 & 6.9 & 0.45 & 2160 & 4.00 \\
$32-6,41-44$ & 2.02 & 0.12 & 0.06 & 4 & 0.95 \\
$39-2,43-46$ & 3.68 & 1.1 & 0.30 & 150 & 0.99 \\
$44-1,123-125$ & 2.94 & 1.2 & 0.39 & 135 & 1.07 \\
\hline & & & & &
\end{tabular}

composition were made, using the classification in Table 5. Liptinite and amorphous kerogen represent hydrogen-rich organic matter which is either structured (spores, algae, etc.) or structureless, respectively. Vitrinite represents hydrogen-lean organic matter, typically derived from land plants. Inertinite includes thermally inert macerals such as fusinite, semi-fusinite, and micrinite.

Differences in the types of organic matter observed visually (Table 5) appear to be related to the previously observed differences in chemical composition.

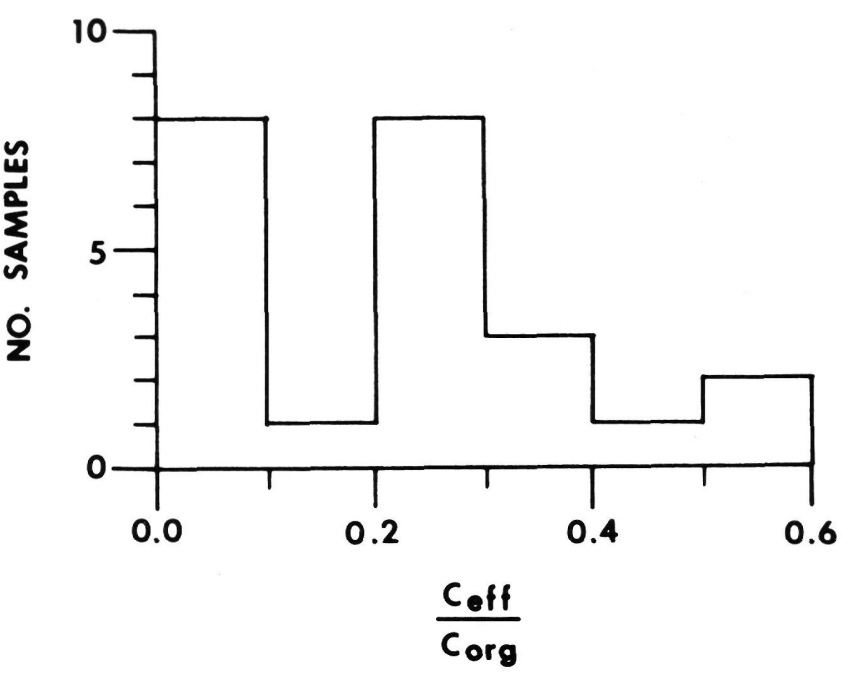

Figure 6. Histogram of $C_{\text {eff }} / C_{\text {org }}$ values.

TABLE 5

Visual Abundance Estimates of Types of Organic Matter ${ }^{\mathbf{a}}$

\begin{tabular}{|c|c|c|c|}
\hline $\begin{array}{c}\text { Sample } \\
\text { (Interval in } \mathrm{cm} \text { ) }\end{array}$ & $\begin{array}{c}\text { Amorphous } \\
\text { Kerogen }\end{array}$ & Liptinite & Vitrinite \\
\hline
\end{tabular}

\begin{tabular}{lllll}
\hline Site 386 & \multicolumn{5}{l}{} \\
$43-3,103-107$ & 7 & 1 & 4 & 3 \\
$43-3,107-110$ & 7 & 1 & 1 & 2 \\
$44-4,134-137$ & 2 & 1 & 7 & 1 \\
$44-4,137-141$ & 1 & 1 & 7 & 1 \\
$44-4,141-145$ & 1 & 1 & 6 & 5 \\
$44-4,145-150$ & 1 & 1 & 6 & 2 \\
$45-4,66-68$ & 2 & 1 & 7 & 4 \\
$45-4,68-72$ & 1 & 1 & 7 & 4 \\
$47-4,27-31$ & 2 & 1 & 6 & 4 \\
$47-4,43-45$ & 1 & 1 & 6 & 5 \\
$61-1,115-118$ & 1 & 1 & 7 & 4 \\
$61-1,129-133$ & 1 & 1 & 7 & 3 \\
$61-2,10-15$ & 1 & 1 & 7 & 4 \\
Site 387 & \multicolumn{5}{l}{} \\
$30-1,142-144$ & 7 & 1 & 2 & 2 \\
$32-6,41-44$ & 1 & 2 & 6 & 4 \\
$39-2,43-46$ & 1 & 1 & 6 & 5 \\
$44-1,123-125$ & 1 & 1 & 7 & 4 \\
\hline aNumerical abundance scale and percentages (by area): $1=0-1 \% ;$ \\
$2=2-5 \% ; 3=6-10 \% ; 4=11-25 \% ; 5=26-50 \% ; 6=51-75 \% ;$ \\
$7=76-100 \%$.
\end{tabular}

Sediments with high values of $\mathrm{H} / \mathrm{C}$ and $\mathrm{C}_{\mathrm{eff}} / \mathrm{C}_{\mathrm{org}}$ contain very abundant amorphous kerogen, implying that the amorphous kerogen represents marine organic matter. Samples with low and intermediate values of $\mathrm{C}_{\mathrm{eff}} / \mathrm{C}_{\mathrm{org}}$ contain greater proportions of vitrinite and inertinite, indicating a stronger influence of terrigenous organic matter. While the chemical data suggest that samples with intermediate values of $\mathrm{C}_{\mathrm{eff}} / \mathrm{C}_{\mathrm{org}}$ should contain appreciable amounts of marine organic matter, very little amorphous kerogen is actually observed in such samples. The apparent absence of amorphous kerogen may reflect the difficulty in discerning small amounts of diffuse organic matter, or, alternatively, may indicate that kerogens of intermediate composi- 
tion actually consist of land-plant material which is relatively rich in hydrogen and oxygen.

The evidence of both chemical analyses and visual observations indicate that land-derived organic matter strongly influences the composition of organic matter in the sediments. In view of the large distance from land $(\sim 1000 \mathrm{~km})$, it is initially surprising to find such a large component of terrigenous organic matter in sediments on the Bermuda Rise. The mineralogy of the sediments, however, provides additional support for the continental origin of sedimentary components in the black clay unit. X-ray diffraction analysis of the sediments from Cores 43 and 44 (Site 386) indicates that the following mineral components are present (in order of decreasing abundance:

Quartz
Clay
-Illite
- Kaolinite
- Montmorillonite
Pyrite
Calcite
Feldspar

The continental origin of the sediments is certainly indicated by the abundance of quartz and feldspar as well as clay minerals such as kaolinite and illite (Biscaye, 1965).

\section{Iron and Sulfur Geochemistry}

In examining the black clay sequence, it is interesting to consider the geochemical conditions which existed during deposition of the sediments and how variations in these conditions affected the composition of the organic matter which was preserved.

In order to determine the oxidation-reduction conditions during deposition of the black clays, the distribution of iron and sulfur within the sediments was examined. Because both elements have more than one valence, their geochemical behavior may be significantly influenced by the oxidation potential of the system in which they occur. Of particular importance is the biochemical reduction of sulfate to sulfide in anaerobic sedimentary environments. The $\mathrm{H}_{2} \mathrm{~S}$ which forms as a product of this process may be preserved in the sediments as insoluble iron sulfides or as other sulfur-bearing compounds.

In analyzing the distribution of sulfur, it was assumed that all sulfur occurred in a reduced form and that the reduced sulfur was present either as pyrite or as organic sulfur in the kerogen. The distribution of iron between pyritic and non-pyritic phases was also considered. It was assumed that non-pyrite iron is associated with silicate minerals, especially clays (Goldhaber and Kaplan, 1974), although a significant fraction of the non-pyrite iron in some sediments may also occur as siderite (see smear slide analyses in respective site summary chapters).

The data in Table 6 summarize how iron and sulfur are distributed among the different sedimentary components. In none of the samples is all of the iron
TABLE 6

Iron, Sulfur Contents of Whole Sediment Samples (per cent)

\begin{tabular}{lcccccc}
\hline $\begin{array}{c}\text { Sample } \\
\text { (Interval in cm) }\end{array}$ & $\mathrm{Fe}_{\text {Total }}{ }^{\mathrm{a}}$ & $\mathrm{Fe}_{\text {Pyrite }}{ }^{\mathrm{b}}$ & $\mathrm{Fe}_{\text {Silicate }}{ }^{\mathrm{c}}$ & $\mathrm{S}_{\text {Total }}{ }^{\mathrm{a}}$ & $\mathrm{S}_{\text {Organic }}{ }^{\mathrm{b}}$ & $\mathrm{S}_{\text {Pyrite }}{ }^{\mathrm{b}}$ \\
\hline Site 386 & & & & & & \\
$43-3,103-107$ & 2.46 & 1.98 & 0.48 & 4.12 & 1.69 & 2.26 \\
$43-3,107-110$ & 1.76 & 1.25 & 0.51 & 2.97 & 1.21 & 1.44 \\
$44-4,129-134$ & 2.53 & 0.5 & 2.0 & 0.32 & - & - \\
$44-4,134-137$ & 5.44 & 0.52 & 4.92 & 0.76 & 0.14 & 0.60 \\
$44-4,137-141$ & 2.22 & 1.10 & 1.12 & 1.71 & 0.20 & 1.27 \\
$44-4,141-145$ & 1.90 & 1.36 & 0.54 & 2.04 & 0.09 & 1.56 \\
$44-4,145-150$ & 1.13 & 0.70 & 0.43 & 0.92 & 0.12 & 0.81 \\
$47-4,27-31$ & 1.06 & 0.36 & 0.70 & 0.48 & 0.04 & 0.41 \\
$47-4,37-39$ & 2.53 & 0.36 & 2.17 & 0.61 & 0.07 & 0.42 \\
$41-4,43-45$ & 2.47 & 0.34 & 2.13 & 0.40 & 0.0 & 0.39 \\
$61-1,133-129$ & 3.88 & 0.76 & 3.12 & 1.02 & 0.08 & 0.88 \\
Site 387 & & & & & & \\
$30-1,142-144$ & 2.70 & 2.34 & 0.36 & 4.00 & 1.07 & 2.69 \\
$39-2,43-46$ & 1.40 & 0.58 & 0.82 & 0.99 & 0.26 & 0.67 \\
\hline
\end{tabular}

${ }^{\mathrm{a}}$ Direct measurement.

${ }^{b}$ Computed from kerogen composition,

${ }^{c}$ Computed as difference of $\mathrm{Fe}_{\text {total }}-\mathrm{Fe}$ pyrite

partitioned into one phase or another, but the distribution of iron between the sulfide and silicate phases changes dramatically as the sulfur contents of the sediments increase (Figure 7). Sediments with low amounts of total sulfur (less than 1 per cent) exhibit relatively high ratios $(0.5$ to 9.5$)$ of silicate iron $\left(\mathrm{Fe}_{\text {sil }}\right)$ to pyrite iron $\left(\mathrm{Fe}_{\mathrm{pyr}}\right)$. Sediments with total sulfur contents greater than 1 per cent, on the other hand, have $\mathrm{Fe}_{\text {sil }} / \mathrm{Fe}_{\text {pyr }}$ ratios less than 2.0, reflecting an increased proportion of iron occurring as sulfide.

The observed changes in the distribution of iron are accompanied by changes in the composition of organic matter. Sediments exhibiting relatively high $\mathrm{Fe}_{\text {sil }} / \mathrm{Fe}_{\text {pyr }}$ ratios have $\mathrm{C}_{\mathrm{eff}} / \mathrm{C}_{\text {org }}$ values less than 0.1 (Figure 7). Such low values of $\mathrm{C}_{\text {eff }} / \mathrm{C}_{\text {org }}$ were previously inferred to represent thermally inert or humic, land-plant organic

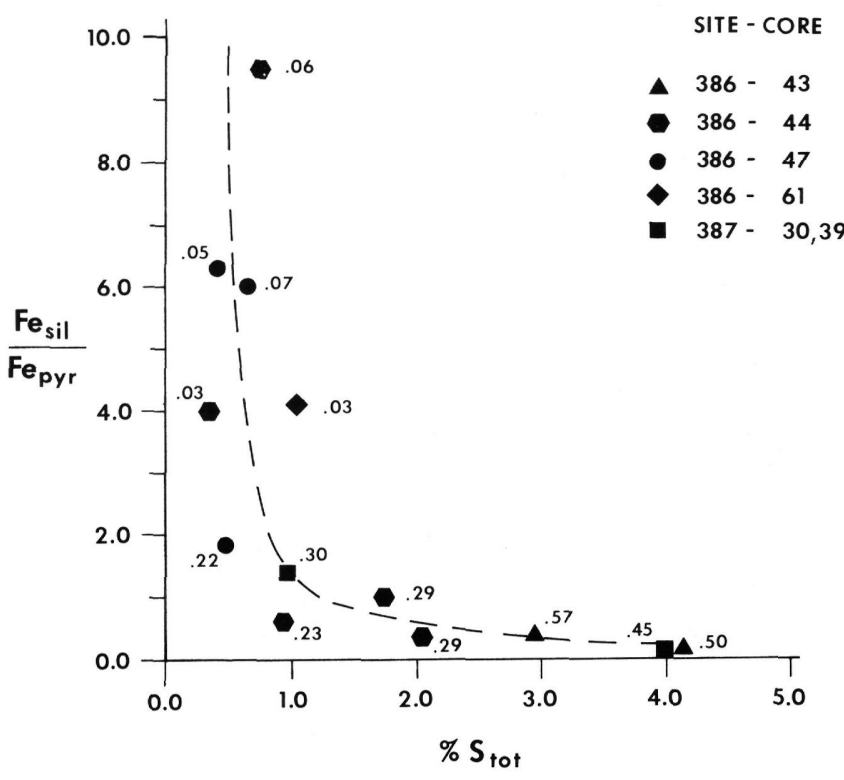

Figure 7. Graph depicting the ratio of silicate iron $\left(\mathrm{Fe}_{\text {sil }}\right)$ to pyrite iron $\left(\mathrm{Fe}_{\text {pyr }}\right)$ as a function of total sulfur content of the sediments. The numbers beside each point represent the $C_{\text {eff }} / C_{\text {org }}$ ratio of the sample. 
matter. Samples with lower $\mathrm{Fe}_{\text {sil }} / \mathrm{Fe}_{\mathrm{pyr}}$ values exhibit increasing ratios of $\mathrm{C}_{\mathrm{eff}} / \mathrm{C}_{\mathrm{org}}$, indicating a greater component of marine organic matter.

The observed variations in iron distribution and composition of organic matter appear to reflect differences between aerobic and anaerobic environments of deposition. Sediments containing small amounts of sulfur and containing predominantly non-pyrite iron were probably deposited under aerobic conditions. During the deposition of these sediments either bottom water circulation supplied sufficient oxygen for the decomposition of organic matter, or the supply of organic matter was not great enough to place excessive demands on the dissolved oxygen supply of the deep waters. While the greenish color of some sediments implies that conditions were sufficiently reducing for the formation of ferrous iron, the occurrence of burrow mottling confirms that enough dissolved oxygen was present for aerobic organisms to live in this environment. The low sulfur contents of these sediments imply that sulfate reduction was of minor importance. If the sediments contained 80 to 85 per cent water when they were deposited, then sulfur contents of 0.4 to 0.5 per cent can be attributed to sulfur present in the interstitial waters at the time of deposition.

The inferred development of anaerobic conditions in the black clay unit is manifested by larger proportions of pyrite iron and higher sulfur contents of some sediments. Sulfur contents greater than those calculated from the original volume of interstitial waters imply that additional amounts of sulfur were partitioned from seawater into the sediments by sulfate reduction. The available data do not indicate, however, whether anaerobic conditions existed in the waters above the sea floor or only below the sediment-water interface.

In anaerobic basins such as the Black Sea or the Cariaco Trough, $\mathrm{H}_{2} \mathrm{~S}$ is present in the bottom waters of the basins. It is reasonable to expect that sulfur could be directly incorporated into the surface sediments of such basins. Alternatively, in sediments where anaerobic conditions develop a short distance (several centimeters) below the sediment/water interface, sulfate could diffuse from seawater into the interstitial waters as pore water sulfate is depleted by sulfate reduction. The work of Kaplan et al. (1963) on the Santa Barbara Basin and of Berner (1964) on the Gulf of California indicate that sulfate diffusion may contribute significant amounts of sulfur to sediments which have been deposited in oxygen-deficient waters.

In both anaerobic and dysaerobic environments the sediments may act as an open system, drawing on an infinite reservoir of seawater sulfur. In a dysaerobic environment, however, it is conceivable that rates of diffusion might limit the amount of sulfur which is ultimately incorporated into the sediments. Measured values of sulfur in the Gulf of California, for instance, do not exceed 2 per cent (Berner, 1964).

The Cretaceous black clays in the Atlantic have sulfur contents in excess of 4 per cent, but the accumulation rates of the black clays (see Site 386 and 387 summary chapters) are one or two orders of magnitude smaller than those reported for sediments in modern dysaerobic environments, such as the Gulf of California (Van Andel, 1964). The slow rates of black clay sedimentation imply that sufficient time existed for extensive diffusion of sulfate into the sediments.

As a result, it is difficult to infer whether the deep waters of the North Atlantic Ocean were completely anoxic during black clay sedimentation. Evidence of alternately aerobic and anaerobic conditions within the black clay unit suggests that deep water circulation was occasionally rapid enough to oxygenate the waters above the sea floor. Moderate rates of circulation might have been sufficient to prevent anoxic conditions from developing above the sediment/water interface. The existence of dysaerobic water conditions does not necessarily imply, however, that reducing conditions were limited to sediments within an oxygen minimum layer. Calculations of depths of deposition for the sediments at Sites 386,387 , and 105 indicate that reducing conditions extended to the deepest parts of the northwestern Atlantic basin (McCave, this volume).

Redox conditions within the sediments strongly affect the composition of the organic matter which is preserved. The terrestrial organic detritus that constitutes the organic fraction of aerobic sediments appears to represent organic matter which is most resistant to biochemical destruction. The more reactive marine organic matter is not preserved. In sediments deposited under more reducing conditions, the amount of marine organic matter becomes more pronounced until it eventually overshadows the influence of the terrigenous organic matter, giving the kerogen an increasingly hydrogen-rich composition.

The distribution of sulfur between organic matter and sulfide minerals is also affected by geochemical conditions during sedimentation. As conditions become more reducing, more sulfur is incorporated into the sediments, both as pyrite and as organic sulfur (Table 6 ). Because organic sulfur in sulfur-poor sediments is so scarce (often less than $0.1 \%$ ), the ratio of pyrite sulfur $\left(\mathrm{S}_{\mathrm{pyr}}\right)$ to organic sulfur $\left(\mathrm{S}_{\mathrm{org}}\right)$ tends initially to be highly variable, with values generally greater than 6 . As the total amount of sulfur in the sediment increases, $\mathrm{S}_{\mathrm{pyr}} / \mathrm{S}_{\mathrm{org}}$ drops significantly to values less than 3 .

The relationship between organic sulfur and organic matter is shown in Figures 8 and 9. Figure 8 indicates that organic sulfur contents are linearly related to their organic carbon values. The regression line intersects the abscissa at 1 per cent $C_{\text {org }}$, however, implying that not all organic matter contains sulfur. In this respect, the organic sulfur content appears to be more directly related to the effective carbon content (Figure 9). The differences between Figures 8 and 9 suggest that the amount of sulfur in the kerogen is related to the type of organic matter. The largest amounts of effective carbon and organic sulfur are associated with kerogens whose compositions imply a marine derivation. In contrast, those kerogens with predominantly land- 


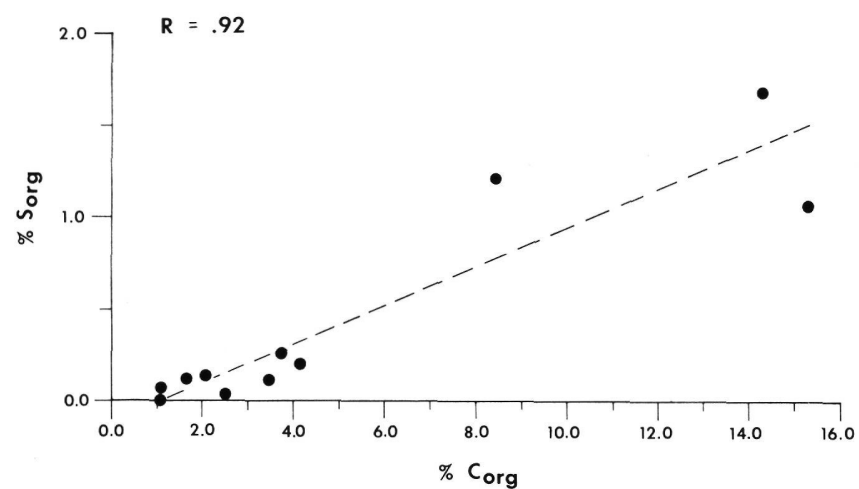

Figure 8. Graph of organic sulfur $\left(S_{\text {org }}\right)$ versus organic carbon $\left(C_{\text {org }}\right) . \mathrm{R}$ is the correlation coefficient of the regression.

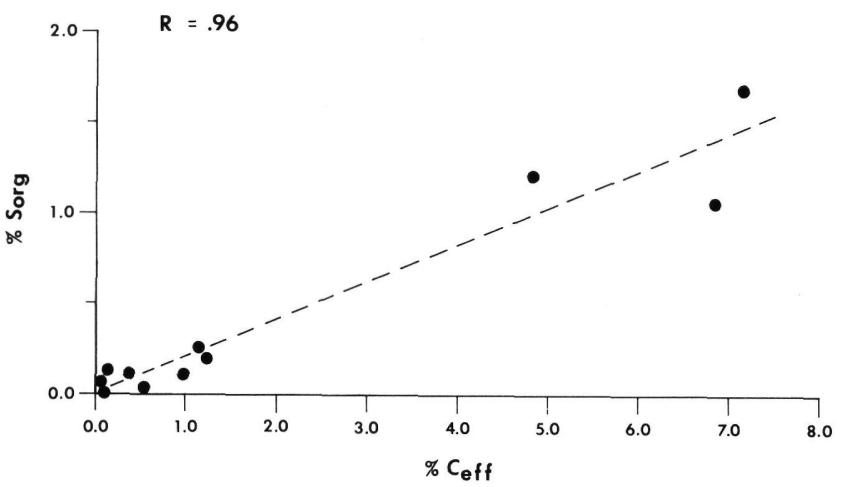

Figure 9. Graph of organic sulfur $\left(S_{\text {org }}\right)$ versus effective carbon $\left(C_{e f f}\right) . \quad \mathrm{R}$ is the correlation coefficient of the regression.

derived organic components have low $\mathrm{C}_{\text {eff }}$ and $\mathrm{S}_{\text {org }}$ contents.

Organic sulfur constitutes as much as 8 per cent of the kerogen in some samples. Such values greatly exceed the sulfur contents (0.3-3.3\%) reported for marine organisms (Goldhaber and Kaplan, 1974), suggesting that much of the organic sulfur is incorporated into the kerogen during diagenesis. Kaplan et al. (1963) arrived at a similar conclusion on the basis of sulfur isotope studies, which indicated that organic sulfur in marine sediments was composed primarily of bacterially reduced sulfur. They suggested that sulfurrich organic matter may represent either low-sulfur organic matter into which sulfur has been biochemically incorporated or the residual organic matter of bacteria which have utilized sulfur in their metabolic activities.

While the results of this study do not indicate how sulfur is incorporated into the final organic matter, they do suggest that sulfur is preferentially included into amorphous, hydrogen-rich organic matter. It was previously noted that amorphous, marine organic matter is preserved only under intensely reducing conditions. Consequently, it appears that redox conditions influence the organic sulfur content of the sediment by controlling the amount of hydrogen-rich kerogen with which sulfur can react.

\section{CONCLUSIONS}

The distribution of iron and sulfur in the Cretaceous sediments at Sites 386 and 387, as well as the composition of organic matter within these sediments, indicates that geochemical conditions varied considerably during deposition of the black clay unit. Commonly, the sediments within the black clay interval are cyclically bedded, grading upward from greenish gray, mottled claystones to dark-colored, laminated claystones. These sedimentary cycles suggest that conditions within the sediments were alternately aerobic and anaerobic, as oxygen in the bottom waters was periodically replenished and then gradually depleted.

McCave (this volume) notes that the distribution of radiolarian sand beds at Site 386 is related to trends in the organic carbon content of the black clay unit. The relationship between these two parameters suggests that organic productivity strongly affected the depositional environment of the clays by controlling the amounts of metabolizable organic matter which were supplied to the sediments. The oxygen demands created by periods of high biological productivity taxed heavily the oxygen supply of the bottom waters. These events led to anaerobic conditions at, or slightly below, the sea floor. As a consequence, substantial amounts of hydrogen-rich, marine organic matter escaped oxidative destruction and were preserved in the sediments. Large amounts of reduced sulfur, generated by bacterial sulfate reduction, were incorporated into the sediments as pyrite or as organically bound sulfur.

Periodically (probably during periods of diminished productivity) deep water circulation was able to supply the dissolved oxygen necessary for metabolism of the sedimented organic debris, and conditions at the seafloor became aerobic. Such conditions restricted the formation of sulfide compounds and limited the amounts of organic matter which were preserved in the sediments. The organic matter that was preserved was mostly recycled land-plant material which was resistant to biochemical destruction.

\section{ACKNOWLEDGMENTS}

The author is sincerely grateful to A. N. Fuex, A. Hood, G. W. M. Lijmbach, P. R. Mommessin, N. I. McCave, and B. E. Tucholke for their comments and suggestions. The manuscript was reviewed by A. N. Fuex, A. Hood, and P. R. Mommessin.

\section{REFERENCES}

Berger, W. H. and von Rad, U., 1972. Cretaceous and Cenozoic sediments from the Atlantic Ocean: in Hayes, D. E., Pimm, A. C., et al., Initial Reports of the Deep Sea Drilling Project, v. 14: Washington (U. S. Government Printing Office) p. 787-954.

Berner, R. A., 1964. Distribution and diagenesis of sulfur in some sediments from the Gulf of California: Marine Geol., v. 1, p. 117-140.

Biscaye, P. E., 1965. Mineralogy and sedimentation of Recent deep-sea clay in the Atlantic Ocean and adjacent seas and oceans: Geol. Soc. Am. Bull., v. 76, p. 803-832.

Boyce, R. E., 1972. Carbon and carbonate analyses, Leg XI. In Hollister, C. D., Ewing, J. I., et al., Initial Reports of 
the Deep Sea Drilling Project, v. 11: Washington (U. S. Government Printing Office), p. 1059-1071.

Goldhaber, M. B. and Kaplan, I. R., 1974. The sulfur cycle. In Goldberg, E. D., (Ed.), The Sea: New York (WileyInterscience), v. 5, p. 569-655.

Heacock, R. L. and Hood, A., 1970. Process for measuring the live carbon content of organic samples: U.S. Patent 3,508,877, April 28, 1970.

Hood, A., Castaño, J. R., and Kendrick, J. W., 1976. Petroleum-generating potential and thermal history of DSDP Leg 38 sediments. In Talwani, M., Udintsev, G., et al., Initial Reports of the Deep Sea Drilling Project, v. 38: Washington (U. S. Government Printing Office), p. 801-803.

Kaplan, I. R., Emery, K. O., and Rittenberg, S. C., 1963. The distribution and isotopic abundance of sulfur in recent marine sediments off southern California: Geochim. Cosmochim. Acta, v. 27, p. 297-331.
Lancelot, Y., Hathaway, J. C., and Hollister, C. D., 1972. Lithology of sediments from the western North Atlantic, Leg XI, Deep Sea Drilling Project. In Ewing, J. I., Hollister, C. D., et al., Initial Reports of the Deep Sea Drilling Project, v. 11: Washington (U. S. Government Printing Office), p. 901-950.

Tissot, B. and Espitalié, J., 1975. L'évolution thermique de la màtiere organique des sediments: Applications d'une simulation mathématique: Rev. Inst. Fr. Petrol., v. 30, p. 743-777.

Tissot, B., Durand, B., and Combaz, A., 1974. Influence of nature and diagenesis of organic matter in formation of petroleum: Am. Assoc. Petrol. Geol. Bull., v. 58, p. 499506.

Van Andel, Tj. H., 1964. Recent marine sediment of Gulf of California. In Van Andel, Tj., H. and Shor, G. G. Jr. (Eds.), Marine geology of the Gulf of California: Am. Assoc. Petrol. Geol. Mem. 3, p. 216-310. 